\title{
Atrocity Crimes in Xinjiang: Moving beyond Legal Labels
}

\author{
Sophie Ryan \\ Researcher at the Asia-Pacific Centre for the Responsibility to Protect and \\ BCL Candidate (Rhodes Scholar) at the University of Oxford, Faculty of Law, \\ Oxford, UK \\ sophie.ryan@magd.ox.ac.uk
}

\begin{abstract}
This article considers the legal tests for establishing genocide and crimes against humanity in relation to the situation in Xinjiang. It suggests that the currently available evidence is likely sufficient to establish atrocity crimes and that the situation in Xinjiang requires urgent international attention, regardless of the precise legal label applied to it.
\end{abstract}

\section{Keywords}

China - Uighurs - atrocity crimes - legal determination

Since early 2017, reports have been emerging of systematic repression of Uighurs and other minority Muslims in China. In recent months, the debate seems to have shifted from whether abuse is occurring in Xinjiang to what that abuse amounts to. Crimes against humanity? Genocide? Both? This article examines the importance of such legal labels and, in brief, 1 the extent to which they might be extended to the situation in Xinjiang. It also argues, however, that debates around legal nomenclature risk obscuring what matters most in

1 For a more thorough examination, see Asia-Pacific Centre for the Responsibility to Protect, Genocide and Crimes against Humanity in Xinjiang? Applying the Legal Tests, Report, November 2020, https://r2pasiapacific.org/files/5818/applying_legal_tests_xinjiang_ nov2020.pdf ('APR2P Centre, Report'). 
the conversation: the Uighurs. The available evidence strongly suggests that atrocity crimes have occurred in Xinjiang. Beyond this, the legal determination of the situation should be beside the point - the Uighurs need urgent support and the international community should respond accordingly.

As a matter of law, the appropriate legal characterisation of the situation in Xinjiang is important because it determines whether states are obliged to do something about it. International law imposes an obligation upon states to prevent (and punish) genocide as soon as becoming aware of a 'serious risk' of genocide. ${ }^{2}$ The same can arguably be said for crimes against humanity, ${ }^{3}$ although there is not yet a dedicated convention like the Genocide Convention clearly expressing such an obligation. ${ }^{4}$ Both crimes constitute violations of jus cogens norms under international law and all states have a legal interest in their prevention (erga omnes). ${ }^{5}$ The effect is that if such crimes have been committed in China, certain legal rights and obligations flow under international law for other states. The $\mathrm{R}_{2} \mathrm{P}$ doctrine gives these legal norms moral and political force by emphasising all states' responsibility to protect populations from genocide, war crimes, crimes against humanity, and ethnic cleansing (commonly referred to as 'atrocity crimes'). ${ }^{6}$ Appropriately labelling a situation therefore generates expectation - it brings it within the $\mathrm{R}_{2} \mathrm{P}$ rubric and as such, is a necessary first step in galvanising international attention and action.

Currently available evidence suggests that China's treatment of the Uighurs involves crimes against humanity, if not also genocide. Under international law, a crime against humanity consists of prohibited acts committed as part of a widespread or systematic attack on any civilian population. ${ }^{7}$ Alleged abuses

2 Convention on the Prevention and Punishment of the Crime of Genocide, 78 UNTS 277 (entered into force 12 January 1951) ('Genocide Convention'), Art I; Case Concerning the Application of the Convention on the Prevention and Punishment of the Crime of Genocide (Bosnia and Herzegovina $v$ Serbia and Montenegro) (Judgment) (ICJ, 26 February 2007), para. 431.

3 See Sean Murphy, First Report on Crimes Against Humanity, UN Doc A/CN.4/68o, 17 February 2015, pt v.

4 But see International Law Commission (ILC), Draft Articles on Prevention and Punishment of Crimes Against Humanity, with commentaries, UN Doc A/74/10 (adopted by the ILC at its 71st sess., 2019) ('ILC, Draft Articles on Crimes Against Humanity, with commentaries').

$5 \quad$ Reservations to the Convention on the Prevention and Punishment of the Crime of Genocide (Advisory Opinion) (ICJ, 28 May 1951) ('Reservations to the Genocide Convention'), 23; Armed Activities on the Territory of the Congo (Democratic Republic of the Congo $v$ Rwanda) (Judgment) (ICJ, 3 February 2006), para. 64; Draft Articles on Crimes Against Humanity, with commentaries, p. 24, paras. 5-6.

6 '2005 World Summit Outcome', UNGA Res. 6o/1, 24 October 2005, paras. 138-139.

7 Rome Statute of the International Criminal Court, 2187 UNTS 3 (entered into force 1 July 2002) ('Rome Statute'), Art 7(1). This definition likely reflects customary international law: see ILC, Draft Articles on Crimes Against Humanity, with commentaries, p. 30, para. 8. 
of the Uighurs include large-scale arbitrary detention and mass surveillance, forced political indoctrination, torture and inhumane treatment, forced sterilisation, forced separation of children from parents, forced labour, sexual violence, and even killings. ${ }^{8}$ The evidence suggesting that many of these abuses are part of a state policy aimed at 'transforming' and, in effect, erasing Uighur identity indicate that they likely reach the threshold of a relevant 'attack' so as to amount to crimes against humanity. ${ }^{9}$

Genocide consists of a prohibited act committed with the intention to 'destroy' a protected group. ${ }^{10}$ Reports suggesting that the aim underpinning China's treatment of the Uighurs is erasure of Uighur culture raise obvious concerns in this regard. However, the narrow definition of genocide under international law also makes a genocide determination difficult. An intention to destroy the Uighur group culturally would fit the concept of genocide initially conceived by Raphael Lemkin, which encompassed acts of political, economic, and cultural destruction as well as physical destruction. ${ }^{11}$ However, the legal definition currently accepted under international law recognises as 'genocide' only what Lemkin saw as the ultimate form of group destruction: physical destruction of the group itself, and only in the particular circumstances enumerated in the Genocide Convention. ${ }^{12}$ In the case of Xinjiang, while there is strong evidence of prohibited acts occurring, the existing evidence relating to an intention to destroy the group physically seems more uncertain. ${ }^{13}$ Arguments can be made that the requisite intention is established on the evidence as it stands, especially considering evidence relating to acts of 'imposing measures intended to prevent births' and 'forcibly transferring children', but arguments can also be made that the situation falls just beyond the bounds of genocide as a matter of law, in the murky area between the legal definition of genocide contained in the Genocide Convention and that initially propounded by Lemkin. ${ }^{14}$

8 See $\mathrm{APR}_{2} \mathrm{P}$ Centre, Report.

9 See further APR2P Centre, Report, pp. 2-13.

10 Genocide Convention, Art II. This definition reflects customary international law: see Reservations to the Genocide Convention, p. 23.

11 Raphael Lemkin, Axis Rule in Occupied Europe: Analysis of Government, Proposals for Redress (Washington DC: Carnegie Endowment for World Peace, 1944), pp. 79, 82, 87-89. See Case Concerning the Application of the Convention on the Prevention and Punishment of the Crime of Genocide (Bosnia and Herzegovina $v$ Serbia and Montenegro) (Judgment) (ICJ, 26 February 2007), para. 344; International Law Commission, Report of the Commission to the General Assembly on the Work of its Forty-First Session, UN Doc A/CN.4/SER.A/1989/Add.1 (Part 2), p. 102, Article 4.

13 See, for example, APR2P Centre, Report, pp. 16-18. ibid. 
An eye to the $\mathrm{R}_{2} \mathrm{P}$ doctrine and the legal norms underpinning it suggests that it should not matter whether the situation in Xinjiang can, at this stage, conclusively be said to be genocide - the international community's responsibility to protect is triggered by the evidence relating to crimes against humanity and a 'serious risk' of genocide. Yet, practice suggests that a certain emotional gravitas attaches to the term 'genocide' that eludes that of 'crimes against humanity' - genocide seems to have become the de facto 'crime of crimes'.15 The result is an absurdity: truly atrocious acts, including those aimed at erasing a group's identity, are sometimes dismissed as less deplorable if they fail to attract the legal label of 'genocide'. In the context of prevention, this means that timely and effective action necessary to fulfil the international community's responsibility to protect can be thwarted by overly linguistic and legalistic discussions focused on fitting a situation into - or outside of - very precisely crafted legal definitions that are probably best reserved for courts and tribunals considering questions of liability.

This reality raises some concerns in relation to current debates regarding whether the situation in Xinjiang is best described as 'genocide' or 'crimes against humanity'. It seems clear that the existing evidence raises serious concerns of atrocity crimes. Does the precise legal label really make a difference to the extreme suffering experienced by Uighurs, or to whether and how the international community should take action? It shouldn't. Just as linguistic debates have historically proven barriers to timely and effective preventative action, ${ }^{16}$ there is a real risk that overly legalistic debates about the terms that may be attached to the situation in Xinjiang might overshadow discussions as to how to protect the Uighurs, especially considering China's status in the international community. Yet, for the reasons outlined above, appropriately labelling the situation is also a necessary first step in galvanising an international response. The path forward therefore seems a narrow one: international actors should call China's treatment of the Uighurs what it is - atrocity crimes - but beyond this, focus on moving conversations away from whether the Uighurs require international support towards what and how such support can be given.

15 See, for example, William A. Schabas, Genocide in International Law: The Crime of Crimes, 2nd ed. (Cambridge: Cambridge University Press, 2009).

16 Brent Beardsley, 'The Endless Debate over the "G Word", Genocide Studies and Prevention 1(1): 79-82 (2006). 